\title{
西マレーシア北部における伝統医療と近代医療に対する マレー系住民の認識
}

\author{
藤井 まい $^{1} \quad$ サロニ・アブドゥル $\quad$ ラニ $^{2}$ 中村 安秀 $^{3}$ \\ Perception of a Rural Malaysian community towards traditional and modern medicine \\ in Northern Peninsular Malaysia
}

\author{
Mai FUJII ${ }^{1}$, Saroni ABDUL RANI ${ }^{2}$ and Yasuhide NAKAMURA ${ }^{3}$
}

Objectives : To clarify the acceptance and pattern of the Malay traditional and modern medicine in a northern Malaysian rural community and their perceptions towards these medical systems.

Methodology : A structured questionnaire survey of Malay residents was conducted in Sedaka, a village in Northern Peninsular Malaysia. The questionnaire requested socio-demographic data, and consultations with medical practitioners and Malay traditional healers (bomoh). Two focus group discussions were conducted to explore the reasons for using or not using modern or traditional medical system.

Results : 383 respondents answered the questionnaire. The mean age of the respondents was $28.5 \pm$ 7.4 (SD). Almost everyone (96.1\%) had ever consulted bomoh. There was no significant association between consultation and socio-democraphic data. In recent consultation, $73.5 \%$ received only modern treatment, $8.8 \%$ went bomoh only, and $17.6 \%$ consulted both medical practitioners and bomoh. In focus group discussions, several reasons were revealed that people prefer to utilize traditional or modern medical system.

Discussion : It was clarified that many rural Malays utilized modern system, as still having traditional belief. Rural Malays perceived that the traditional medical system covered overall matters, while the modern medical system were partial. The group utilizing the traditional medical system also consulted other medical systems, if needed, whereas the group utilizing the modern medical system visited only modern system.

Greater cooperation of the traditional and modern medical systems - as shown by the emergency of integrated medicine elsewhere - may bring about improved healthcare for the rural community with higher level of patient satisfaction and community participation.

Key words : Traditional medicine, Alternative medicine, Spiritual therapy, Integrated medicine, Malaysia, Bomoh

伝統医療，代替医療，精霊信仰，ボモ，マレーシア

\footnotetext{
1 世界保健機関家族と地域保健課（WHO）

2 独立行政法人国際協力機構 (JICA) 二本松訓練所

3 大阪大学大学院人間科学研究科ボランティア人間科学講座

${ }^{1}$ Department of Reproductive Health and Research, Family and Community Health Cluster, World Health Organization (WHO)

${ }^{2}$ Nihonmatsu Training Center, Japan International Cooperation Agency (ICA)

${ }^{3}$ Research Center for Civil Society, Graduate School of Human Sciences, Osaka University
} 


\section{I はじめに}

近年, 統合医療（integrated medicine）への関心 が高まりつつある。地域に拈ける既存の伝統的医 療資源について正確に把握し, 活用していくこと はより持続可能で効果的な援助を行う上でも極め て重要である。世界各地に㧍ける伝統医療の研究 に拧いて，住民にとって伝統医療のほうが使いや すい実態や西洋医療に基づく保健プログラムを既 存の伝統医療システムに組み合わせて行われてい る例等が報告されている（Kroeger and Franken, 1981 ; 氏家, 1997 ; 伊藤ほか, 2005). 大竹 (2004) はアフリカの伝統医療と代替医療の研究の中で, 伝統医療の実践を制度の枠組みから排除するので はなく，それらの知識や技能を保健医療の近代化 政策の中に取り込み，特に農村部において積極的 に活用する政策を展開することが住民の望む七一 リングを提供する事になると述べている。

本研究では西マレーシア北部農村におけるマ レー系住民の近代医療と伝統医療に対する認識を 捉え, 現在における各医療の役割や住民の受療行 動に与える影響について考察することを目的とし た. マレーシアの伝統医療に関する先行研究では 伝統医療の精霊信仰や身体理論に焦点をあてたも のが多い. マレーシアの農村において精霊信仰に 基づく伝統医療が盛んに利用されている実態も報 告されている (Hartog, 1974; Miyazaki, 1992)。こ れらの研究の多くは住民の受療行動を捉えている が, 近代医療が普及した後の近代医療と伝統医療 の位置づけを利用者側から捉えた研究は数少ない. そこで本研究では伝統医療が最も盛んな地域で ある西マレーシア北部のマレー系住民を対象に， 伝統医療と近代医療の使い分け及び認識について の実態調査を行った.

マレー系住民が居住する地域には，“bomoh” （ボモ）という伝統的治療者が存在している. Winstedt（1961）によれば，ボモはマレー系住民 のコミュニティの中で活動している医療従事者で あり, 特に霊的世界との媒介を専門とし, 様々な 疾患の治療にあたる者とされている.また, Gimlette
（1915）はボモについて「呪術を使って癒しを施 行している者」と定義している，本論文ではボモ が行う医療を「伝統医療」という。これに対比す る意味で「近代医療」をマレーシア国内外で医師 免許を取得した医師が行う医療（主に診療所, 病 院などにおける医療）と定義した。

\section{II 対象と方法}

対象地域は西マレーシア北部から 1 州（ケダ州） を選び, 調査協力の同意の得られた 1 村, 及び住 民が利用する伝統医療施設とした。

対象地域の村に在住する全住民 385 人のうち, マレー系住民 383 人を調査対象とし質問紙による 調查を実施した。本調査の調査員として, 同村の 出身者で調査対象と同じ民族属性のマレー系住民 の 2 名を選び, 調査方法について 2 日間の研修を 行った. 予め調查員が各家庭を訪問し, 調査の趣 旨および調查を拒否しても不利益がないことを説 明し，調査の同意を得られた家庭のみに訪問した。 質問紙法による面接聞き取り調査で得られた データから, 伝統医療受診群と近代医療受診群を 選択し，それぞれの対象グループについてフォー カス・グループ・ディスカッションを行った。 フォーカス・グループ・ディスカッションについ ても予め対象者に拒否しても不利益がないことを 説明し, 同意を得た．質問紙法およびフォーカ ス・グループ・ディスカッションで使用した調査 言語は，マレー系住民が母国語とするマレー語と した。

\section{1. 伝統医療利用状況実態調査}

対象者 383 人に対し, 質問紙を用いた調査員に よる面接聞き取り法を行った。調査期間は, 予備 調查を 1998 年 6 月, 本調查を 1998 年 8 月に実施 した. 18 歳未満の対象者については予め保護者の 同意を得て, 過去の受診についての項目を保護者 が回答した。

調査項目は基本的属性（性別, 年齢, 教育歴, 収入月額, 婚姻状況, 職業, 宗教）の他,「これ までに一度でも伝統医受診をした事があるか」,「過 
去 3 か月以内に受診をしたか」,「第一選択として 近代医療, 伝統医療のどちらの受診をしたか」等 であった。

伝統医受診の有無と性別，年龄階層，教育歴， 収入額，婚姻状況との関連を検討するため， $\chi^{2}$ 検 定または Fisher の直接確率計算法による検定を 行った. データの分析については統計パッケージ SPSS を使用した.

\section{2. 伝統医療，近代医療に対する認識調査}

質問紙調査の結果をもとに，伝統医療受診群と 近代医療受診群を選択し，各々についてフォーカ ス・グループ・ディスカッションを行った。 フォーカス・グループのファシリテーターは同村 の出身者で調查対象と同じ民族属性のマレー系民 族の調查員とした。

先に行われた質問紙による調査で，過去 3 か月 以内に受診したと答えた人について直近の有症時 に近代医療と伝統医療のどちらの受診が良いと判 断したかを尋ね，伝統医療を選択する群と近代医 療を選択する群に分けた。これらの群からそれぞ れ 5 人を選出した。この 2 つのグループに対し， 別々にフォーカス・グループ・ディスカッション を行った．主な内容は伝統医療或いは近代医療の 受搒理由，その他の医療システムの利用状況，伝 統医療および近代医療受診を第一選択とすべき疾 患についてなどであった。

\section{III 結果}

\section{1. 伝統医療利用状況実態調査}

1）基本的属性

383 人から回答を得た（有効回答率 $100 \%$ ）。有 効回答者の性別は男性が 188 人（49.1\%)，女性 が 195 人（50.9\%）であった，年齢構成は，0-20 歳，21-40 歳，41-60 歳，61 歳以上がそれぞれ， 166 人 $(43.3 \%), 103$ 人 $(26.9 \%), 73$ 人 $(19.1 \%)$, 41 人 $(10.7 \%)$ であった. 平均年歯は $28.5 \pm 7.4(S D)$ 歳であった。

1 家庭あたりの月収平均は RM0-300（マレーシ アリンギット（RM）: $1 \mathrm{RM}=32$ 円）が 159 人
(41.5\%)，RM 301-500 が 114 人 (29.8\%), RM 501 以上が 110 人 $(28.7 \%)$ であった. マレーシ ア全体におけるプランテーションの平均覒金 （1999）は RM 550 といわれ，調查対象地の平均収 入よりも高い。しかし，調査地の農村では現金収 入は少ないが，ほぼ全員が持ち家に住み，米，野 菜，魚などは自給自足していた。婚姻状況は既婚 が 149 人 $(38.9 \%)$ ，未婚が 208 人 $(54.3 \%)$, 離 婚が 2 人 $(0.5 \%)$, 死別が 24 人 $(6.3 \%)$ であっ た。

調査対象者 383 人のうち，18 歳以上の人は 231 人であった。これらの人を対象に最終学歷，職業， 宗教について質問した．最終学歴は未就学者が 40 人 $(17.3 \%)$, 初等教育が 67 人 $(29.0 \%)$, 中等教 育が 117 人 $(50.6 \%)$ ，高等教育以上が 7 人 $(3.0 \%)$ であった。職業は無職が 101 人 (43.7\%), 農業 が 57 人 (24.7\%), 工場勤務が 32 人 (13.9\%), その他が 41 人 (17.7\%) であった．宗教は全員が イスラム教であった。

2）伝統医受診歴の有無と内容

有効回答の得られた 383 人のうち，「これまで 1 度でも伝統医療（ボモ）による治療を受けたこ

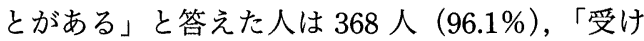
たことがない」と答えた人はで 15 人 $(3.9 \%)$ で あった（表 1)。伝統医受診の有無を性別，年柃階 層，教育歷，収入額，婚姻状況別に関連を検討し たが，有意な差は認められなかった。

3）過去 3 か月以内の受診状況

過去 3 か月以内に括ける受診の有無については, 「受診あり」と答えた人は 34 人 $(8.9 \%)$ であっ た。この 34 人に対し，直近の疾病時の受診状況 を尋ねた。近代医療を受診した人は 25 人 $(73.5 \%)$, 伝統医療を受診した人は 3 人 $(8.8 \%)$ ，両方とも 受診したと答えた人は 6 人 $(17.6 \%)$ であった (表 2).

\section{2. 伝統医療，近代医療に対する認識調查} 伝統医療受診群と近代医療受診群にフォーカ ス・グループ・ディスカッションを行った。 
表 1 対象者の属性と伝統医受診の有無

\begin{tabular}{|c|c|c|c|c|c|c|}
\hline \multirow[t]{2}{*}{ 項目 } & \multirow[t]{2}{*}{ カテゴリー } & \multicolumn{2}{|c|}{ 伝統医受診あり } & \multicolumn{2}{|c|}{ 伝統医受診なし } & \multirow[t]{2}{*}{ 検定 } \\
\hline & & $\mathrm{n}$ & $\%$ & $\mathrm{n}$ & $\%$ & \\
\hline \multirow[t]{2}{*}{ 性別 } & 男 & 180 & $(47.0)$ & 8 & (2.1) & N.S. \\
\hline & 女 & 188 & $(49.1)$ & 7 & (1.8) & \\
\hline \multirow[t]{2}{*}{ 年齢階層 } & $20-40$ & 260 & $(67.9)$ & 9 & (2.3) & N.S. \\
\hline & $41^{-}$ & 108 & $(28.2)$ & 6 & (1.6) & \\
\hline \multirow[t]{2}{*}{ 教育歴 } & 初等教育まで & 212 & $(55.4)$ & 7 & (1.8) & N.S. \\
\hline & 中等教育以上 & 156 & $(40.7)$ & 8 & $(2.1)$ & \\
\hline \multirow[t]{2}{*}{ 月収 } & RM0-500 & 265 & $(69.2)$ & 8 & $(2.1)$ & N.S. \\
\hline & RM500- & 103 & $(26.9)$ & 7 & (1.8) & \\
\hline \multirow[t]{2}{*}{ 婚姻状況 } & 既婚 & 142 & $(37.1)$ & 7 & (1.8) & N.S. \\
\hline & 未婚, 離婚, 死別 & 226 & $(59.0)$ & 8 & $(2.1)$ & \\
\hline
\end{tabular}

$\mathrm{RM}$ ：マレーシアリンギット

表 2 過去 3 か月以内の受診状況

\begin{tabular}{lrc}
\hline \multicolumn{1}{c}{ 受診 } & $\mathrm{n}$ & $\%$ \\
\hline 近代医療のみ & 25 & 73.5 \\
伝統医療のみ & 3 & 8.8 \\
両方 & 6 & 17.6 \\
\hline 合計 & 34 & 100 \\
\hline
\end{tabular}

1）伝統医療受診群

（1）伝統医療を受診する理由

伝統医療に対する受療行動について受診群の伝 統医療を受診する理由は「伝統医療はどんな病気 も扱ってくれるので満足できる」，「今までずっと 伝統医にいっていた。そういう習慣である」、「伝 統医は村の中にいるから」などであった。
（2）近代医療を受診しない理由 近代医療を受診しない理由は「近代医療は身体 面の事しか扱わない」「全ての病気に対応してく れるわけではない」などであった（表 3）.

（3）その他の医療の利用状況

伝統医療以外に利用する医療について，「病院， 診療所にも行く」,「中国系住民が利用する薬草を 買いに行くことがある」,「肩こりや腰痛には日本 の磁気ベルトを使用する」などの回答があった．

（4）伝統医療を受診する疾患

医療第一選択として伝統医療を受診する疾患を 尋ねた。

「頭痛，腹痛，歯痛」「突然泣き出したり，叫 んだりする，或いは失禁するなどといった奇怪な

表 3 伝統医療 ・近代医療別の受診, 非受診の理由

\begin{tabular}{|c|c|c|}
\hline グループ & 伝統医療 & 近代医療 \\
\hline 伝統医療受診群 & $\begin{array}{l}\text { 「伝統医療はどんな病気も扱ってくれる } \\
\text { ので満足できる」 } \\
\text { 「今までずっと伝統医に行っていた．そ } \\
\text { ういう習慣である」 } \\
\text { 「伝統医は村の中にいるから」 }\end{array}$ & $\begin{array}{l}\text { 「近代医療は身体面の事しか扱わな } \\
\text { い」 } \\
\text { 「全ての病気に対応してくれるわけ } \\
\text { ではない」 }\end{array}$ \\
\hline 近代医療受診群 & $\begin{array}{l}\text { 「イスラム教の信仰が強いから」「病院 } \\
\text { 受診がすでに習慣になっているから」 } \\
\text { 「自分の病気は伝統医療の治療法と合わ } \\
\text { ないから」 } \\
\text { 「伝統医療は古い」 } \\
\text { 「伝統医療は病気の診断が不正確」 }\end{array}$ & $\begin{array}{l}\text { 「病院受診がすでに習慣になってい } \\
\text { るから」 } \\
\text { 「近代医療のほうが進んでいるし, } \\
\text { 特に慢性の病気にはたくさんのい } \\
\text { い薬も出ている」 } \\
\text { 「近代医療のほうが便利だから」 }\end{array}$ \\
\hline
\end{tabular}


行動」,「原因不明で湿疹と共に熱が出た場合」, 「骨折」,「痛みによる後遺症」,「手足が腫れたり してマッサージが効くと思ったとき」，「近代医療 で検沓結果異常なしといわれたりして，原因がわ からなかった時」、緊張，筋肉痛，呪いをかけら れたとき，ヒステリー症状，赤ちゃんの夜泣き （近代䀢療だと，異常なしといわれるような病気） など」,「軽い頭痛や腹痛，気分不快」、「誰かに呪 われたりしたと考えられる場合」などの回答があっ た.

2）近代医䝤受診群

（1）近代医療を受診する理由

近代医療を受診する理由は，「病院受診がすで に習慣になっているから」,「自分の病気（糖尿病， 高血压）は伝統医䝤の治㙩法とあわないから」, 「近代医療のほうが進んでいるし，特に慢性の病 気にはたくさんのいい薬も出ている」、「近代医療 のほうが便利だから」などであった

（2）伝統医療を受㟝しない理由

伝統医を受部しない理由は「イスラム教の信仰 が強いから」「病院受晾がすでに習慣になってい るから」,「自分の病気（糖尿病，高血圧）は伝統 䀢療の治療法とあわないから」等に加え「古い」, 「病気の診断が不正確」などであった（表 3）.

（3）その他の医療の利用状況

全貣が「病院以外は行かない」と答えていた.

（4）近代医療受診を第一選択とすべき疾患

第一選択として近代医療を受診する疾患は，「マ ラリア，デング熱等の熱带苪」「赤ちゃんの湿疹, 妊婦の不調等の母子の疾患」,「怪我」などの回答 があった。

伝統医療における「精霊信仰」については，全 員が「それは信じている」と回答した。

\section{IV 考察}

マレーシア北部農村のマレー系住民を対象に全 数調查を行った結果, 対象者の大多数がボモと呼 ばれる伝統医の受診経験があった。

過去 3 か月以内の受療行動では，住民の多くが 近代医療を利用する一方，伝統医療の利用もあっ
た.マレー系住民の受療行動について, 板垣 (2003) は近代療法と伝統医の受㟝や薬草の使用を含む民 間療法がほぼ同頻度で利用されている現状を報告 している，本調查で，同一疾患に対して両方の医

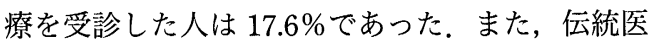
療における精霞信仰については対象者全員が「信 じている」と答えており，精霊信仰はマレー系住 民の間で広く存在することが示唆された。

本調查の結果から，マレー系住民は精霊の信仰 を継続しながら近代医療も利用するようになった という実態が明らかになった。本研究で近代䀢療 は，主に診療所，病院などにおける医療と定義し たが，これらは西洋医療を基盤として発展してき た医療と捉えることができる，精霊の出入りを信 じるマレー系住民の多くが異なる概念に基づく近 代医療を受診している現状を踏まえ，住民の伝統 医療や近代医療に対する認識について受診と受療 行動の観点から考察する.

\section{1. 伝統医療の受診}

マレーシアにおいて農村部に近代医療施設が普 及したのは 1950 年代からとされるが (Chen, 1979a），近代医療の普及により，住民の判断で近 代医療と伝統医療を使い分けるようになったこと が指摘されている (Chen, 1975 ; Chen, 1979b). 過去 3 か月以内の受診状況では住民の大多数が近 代医療を利用していたが，伝統医療の受診もあっ た。フォーカス・グループ・ディスカッションで 伝統医療受診群があげた回答をもとに，第一選択 として伝統医療が選択される場合を下記の 3 つに 分けて考察した。

1）精霊の除去を目的とする場合

住民の回答では「誰かに呪われた時」があげら れていた。マレー系住民の間で精霊信仰が広く存 在することは先行研究で明らかになっている (Paul, 1975 ; Hartog, 1974 ; Miyazaki, 1992). 板垣 （2003）はマレー系住民にとっての病気は「一目 で確認できる症状ではなく，その症状を引き起こ している病因（asar penyakit）によって固定され る」としている、マレー系住民は有症時にその症 
状改善に焦点を当てるのではなく，病因と思われ る精霊への対処を考えるのではないかと推測され た．住民は精霊信仰に基づく対応を伝統医に期待 しているため伝統医療の受診をすると考えられた。

2）伝統医（ボモ）と近代医の治療で伝統医の ほうがより専門性が高いと判断した場合 伝統医の中には 1 つの専門分野に特化して治療 を行うものがいることが先行研究などで明らかに なっている，板垣（2003）はマレー系住民の伝統 医療に関する研究の中で，16 種類の伝統医（ボ モ）を紹介している，住民の回答で得られた「マッ サージ」や「骨折」も板垣の報告によれば，「マッ サージのボモ」や「骨折のボモ」として，専門性 を持つものが存在するとされる，住民は，マッサー ジや骨折の治療においては近代医療より伝統医療 の治療を信頼していることが伝統医療受診選択に つながると推測された。本調査では住民の伝統医 療選択に係る理由として骨折などの回答が得られ たが，その具体的な治療がどのようなものである か，その中のどの部分に対して住民の信頼がある のかについては今後詳細な検討が必要であろう.

3）近代医療の適用外の症状の場合

伝統医療受診群は，近代医療では病気とみなさ れない場合や検査等で原因が特定できない場合に も伝統医療を受診すべきと答えていた. Paul (1975) は, マレー系住民にとっての病気とは「魂（semangat）が無くなった状態」または「不適切な行い」 が原因で起こる不調であると説明している。この ことより，住民の回答にあった「緊張」や「筋肉 痛」等は近代医療では治療対象とされないが，住 民は病気と捉えている可能性が多分にあると考元 られた。住民の認識する「病気」と，近代医療で 対応する「病気」との間に何らかの相違があり, これらの間を埋める位置づけとして伝統医療の役 割があるのでないかと考元れた。

\section{2. 近代医療の受診}

近代医療受診群は近代医療を受診する理由とし てイスラムの信仰心の他, 特定の疾患に対しての 近代䀢療への信頼をあげていた。
1）イスラム信仰心

マレー系住民の農村は精霊信仰が古来より存在 するが，15 世紀にイスラムの普及があったとされ る (Chen, 1974)。本調査でも対象者は全員がイス ラム教であると回答していた. Chen（1974）はマ レー農村における伝統的医療の精霊信仰と近代医 療に関する知識，及びイスラム信仰による理想の 3 つの関係について調查し，伝統的な精霊信仰と イスラム教の理想主義の間で住民に心の葛藤がし ばしば生じることを明らかにしている。また，近 代医療とイスラム信仰との間でも暮藤があると報 告している，本調査では近代医療群の中で「イス ラム教なので伝統医療は受診せず，近代医療を受 診する」との回答があった。住民のイスラム信仰 心と精霊信仰の間に何らかの拮抗的な関係がある 可能性は示唆されたものの, イスラム信仰と近代 医療との関係や伝統医療受診群のイスラム信仰に ついては明らかになっていない.この点について は今後の詳細な調査と慎重な議論が必要であろう。

2）近代医療に対する信頼

近代医療受診群は近代医療受診理由として，糖 尿病や高血圧などの持病の治療をあげていた。ま た「マラリア，デング熱等の熱帯病」などの回 答もあった。

Paul（1975）は，マレー系住民の病気は魂の出 大りや不適切な行いが原因で, 奇行や腹痛, 発熱 など具体的な症状が呈されると考えられており， これらの症状が近代医療でも対応できると判断し た場合に，近代医療を受診すると述べている，得 られた回答が近代医療に基づいた疾患名であるこ とから，住民はいくつかの疾患については近代医 療の診断，治療を信頼しており，そのことが近代 医療受診選択につながつていると考えられた。

また，乳児や妊産婦の不調も近代医療を第一選 択とすべきとされていた。マレーシアでは国家施 策の一環として，農村における保健プログラムを 展開してきた。これにより，人口 4,000 人ごとに 農村地区クリニック (Klinik Desa), 人口 50,000 人ごとに地区病院と同じレベルのメインヘルスセ ンターが配圆された。これらのプログラムの多く 
は母子保健分野に焦点を当てている，マレーシア 福祉サービス省, 保健省が行ったプライマリヘル スケア調査(1983)によれば, 農村部の人口の $92.3 \%$ が近代医療サービスが受けられるようになったと の報告がある．母子の疾患は近代医療を第一選択 とすべきと住民が答えたことは，このような保健 プログラムの効果によるものと思われる.

さらに「怪我」も近代医療を第一選択とすべき との回答があった、「怪我」はマレー語では「luka」 と呼ばれ骨折（patah）とは分けて考光られる，骨 折を除く「外傷の処置」について住民は，近代医 療に期待していると考えられた。

\section{3. 伝統医療, 近代医療の療法選択}

板垣（2003）はマレー系住民の伝統医療に関す る調查で, 療法選択について伝統医と診療所の療 法間の変更が最も多いことを報告している. 本調 查では, 伝統医療受診群は伝統医療の他, 近代医 療やその他の医療の療法選択を行うと答えていた が, 近代医療受搒群は全員が近代医療のみを受診 すると答えており, 近代医療受診から伝統医療一 の療法変更については報告されなかった。 Heggenhougen（1980）はマレー系住民の伝統医療に関す る研究の中で, 伝統医は必要時に近代医療システ ムにも患者を紹介するのが通例であり, 近代医療 受診後に伝統医を再受診した場合でも情緒面のケ アなどが行われており, 補完的な医療の役割を担っ ていると指摘している。これに対し，近代医療は 伝統䀢療をはじめとするその他の医療に理解を示 す事はなく, 疾患の治療を主体としていると述べ ている.

本調査でも対象者全員が精霊信仰を信じると答 えた上で, 近代医療受診群は近代医療受診のみ行 うとの回答が得られた。このことから近代医療受 診群の住民も精霊が体内に入って病気になったと 考えることはあるものの, 近代医が伝統医への紹 介や受診勧奨を行うことはなく，近代医療システ ムの中のみで対応していることが示唆された.

住民の捉えている病気が近代医療の西洋医療に 基づく理論と異なる可能性があること, 近代医療
受診群は伝統医療の精霊信仰を継続しながらも近 代医療のみの受診を行っていることは興味深い点 である。

この点において，住民にとってよりよい䀢療を 提供するためには，近代医療に従事する側も住民 の視点による「病気」を理解し，それらに基づく 他の医療システムをも認めたうえで協調していけ る医療システムを作る事が，ひいては住民の最も 望む癒しに慗がるのではないかと考えられた。

\section{V 結 論}

マレーシアのマレー系住民の伝統医療と近代医 療の利用状況と認識について明らかにするために, 1 農村の全数調査を行った。ほぼ全員が伝統医療 の受診経験があることが明らかになった. 過去 3 ケ 月以内の受診では大多数が近代医療を受診してい た。そのうち，伝統医療も併用していたのは $17.6 \%$ だった。年龄, 性別, 教育歴, 経済状況, 婚姻状 況別に伝統医療受診ありとなしを検討した結果, 有意差は認められなかった。伝統医療における精 霊信仰については全員が信じると答えていた。 レー系住民は精霊の信仰を継続しながら近代医療 も利用するようになったという実態が明らかに なった。

調査で得られた結果を, 伝統医療を受診する群 と近代医療を受診する群に分けた。これらの $2 つ$ の群からそれぞれ 5 人を選定し, 伝統医療受診群 と近代医療受診群のフォーカス・グループ・ディ スカッションを行った.

フォーカス・グループ・ディスカッションの結 果より，住民は伝統医療のほうが包括的であると 捉え, 近代医療は部分的であると認識しているこ とが示唆された。また，他の療法選択に関する項 目では，精霊信仰を対象者全員が「信じる」とし たうえで，伝統医療受診群は伝統医療以外の医療 システムを利用していたのに対し，近代医療受診 群は近代医療施設以外に利用しないと答えていた。 近代医療の他の医療システムに対する認識の薄さ や理解度の低さが，住民の受療行動に影響してい るのではないかと考えられた。近代医療システム 
を多くの住民が利用するようになった行動の背景 で住民は伝統医療の方がより包括的であると認識 していた．また，全員が精霊信仰を信じると言う 回答から，近代医療システムが住民側のニーズに 完全には対応していない可能性が示唆された。こ の対応できない部分を伝統医療が担っているので はないかと考元られた。今後, 近代医療も伝統医 療の要素を取り入れていく事で, 近代医療も住民 にとってより身近なものになることは自明である.

謝辞 : 本研究は 1998 年（平成 10 年）度国際交流基金 アジアセンター事業「次世代リーダーフェローシッ プ・プログラム」の助成によって行われた。調査研究 にご協力下さいましたマレーシア科学大学医学部地域 医療講座（Department of Community Medicine, School of Medical Sciences, University Sains Malaysia) の Professor Wan Manan，そして講座の皆様，及び村民の皆 様に心より感謝いたします，本研究に貴重なご意見を 下さいましたマラヤ大学医学部の Dr. Teng Cheong Lieng, カミルアリフ診療所の故 Dr. Kamil Mohd. Ariff に感謝いたします。そしてご指導下さいました東京大 学大学院医学系研究科国際保健学科国際地域保健学講 座の赤林朗先生, Som-arch Wongkhomthong 先生に深 謝いたします。

なお本研究の一部は 3rd World Conference on Rural Health (WONCA : World Organization of National Colleges Academies)，第 3 回国際家庭医学会総会（1999 年, マレーシアサラワク州）にて発表した。

\section{文献}

Chen PCY (1974) : Socio-cultural foundations of medical practice in rural Malay communities, The Medical Journal of Malaysia, 29(1), 2-6

Chen PCY (1975) : Medical systems in Malaysia, Cultural bases and differential use, Social Science and Medicine, 9, 171-180

Chen PCY (1979a) : Traditional and modern medicine in Malaysia, American Journal of Chinese Medicine, VII (3), 259-275

Chen PCY (1979b) : Traditional and cultural factors in Malaysian Medicine, The Family Practitioner, 3(5), 10-16

Gimlette JD (1915) : Malay poisons and charm cure, Oxford University press, 101-105

Hartog J (1974) : The intervention system for mental and social deviants in Malaysia, Social Science and Medicine, 6, 211-220

Heggenhousen HK (1980): The utilization of traditional medicine-A Malaysian example-, Social Science and Medicine, $14 \mathrm{~B}(1), 39-44$

Horwittz (1978) : Family, kin and friend networks in psychiatric help-seeking, Social Science and Medicine, 12, 297-304

板垣明美（2003）: 癒しと呪いの人類学，春風社，190201

伊藤僚子，品田佳世子，川口陽子（2005）：スマトラ 沖地震・津波後のインドネシアに打ける国際緊急援 助活動について, 口腔衛生学会雑誌, 55(4), 397

Kroeger A and Franken HP (1981) : The educational value of participatory evaluation of primary health care programmes: an experience with four indigenous populations in Ecuador, Social Science and Medicine, 15(4), 535-539

Miyazaki K (1992) : The folk knowledge in Batu PahatHistory and development of Malay magic, Local Societies in Malaysia, 1, 36-51

日本労動研究機構 (2006) : 国別労働情報 ; マレーシア, http://jil.go.jp/jil/kunibetu/kiso/mareshiaP01.htm

大竹英博 (2004)：アフリカの伝統医療と代替医療一 最貧国への医療援助の狭間で一, 看護総合研究, 6(1), 50-52

奥野英子訳（1983）：アジア・太平洋地域のリハビリ テーション：マレーシア，リハビリテーション研究， 44, 15-20, Hatim BC (1983) : Rehabilitation in Asia Pacific, Rehabilitation Research

氏家千絵美（1997）：歴史的文脈によるオーストラリ ア先住民「アボリジニ」の「伝統医療」の役割，医 道の日本，56(11)，5-9

Winstedt Richard (1961) : The Malays : A Cultural History, Kegan Paul, 12-14

(受稿 2006.6.5；受理２007.1.19） 